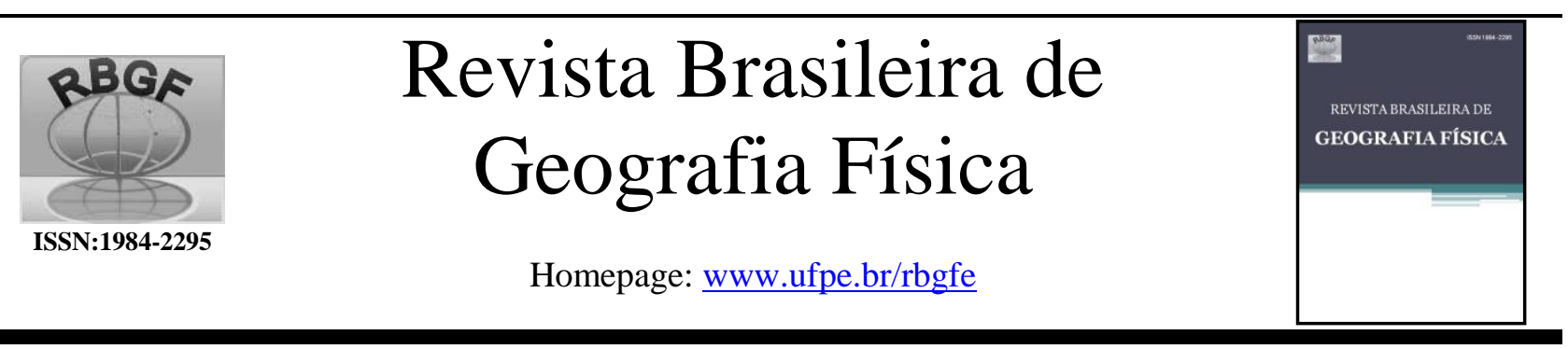

\title{
Stationarity in annual daily maximum streamflow series in the upper Juruá River, western Amazon
}

José Genivaldo do Vale Moreira ${ }^{1}$, Ana Paula Valle Aquino ${ }^{2}$, Anderson Azevedo Mesquita ${ }^{3}$, Marcelo Alves Muniz ${ }^{4}$, Rodrigo Otavio Peréa Serrano ${ }^{5}$.

\begin{abstract}
${ }^{1}$ Dr. Teacher at Federal University of Acre - UFAC, Forest Campus, Canela Fina Road, Km 12, Gleba Formoso, Lote 245, CEP: 69980-00, Cruzeiro do Sul, AC, Brazil. Autor Correspondente: genivaldoufac@ gmail.com; ${ }^{2}$ Forest Engineering Student at Federal University of Acre - UFAC, Forest Campus, Canela Fina Road, Km 12, Gleba

Formoso, Lote 245, CEP: 69980-00, Cruzeiro do Sul, AC, Brazil. annapaula21_czs@ @otmail.com; ${ }^{3}$ Msc. Teacher at

Federal University of Acre - UFAC, Cartography Laboratory, BR 364, km 4, Distrito Industrial, 69920-900, Rio

Branco, AC, Brazil. amgeoufac@ hotmail.com; ${ }^{4}$ Forest Engineering at Federal University of Acre - UFAC, Forest

Campus, Canela Fina Road, Km 12, Gleba Formoso, Lote 245, CEP: 69980-00, Cruzeiro do Sul, AC, Brazil.

engflor.mamuniz@gmail.com; ${ }^{5}$ Dr. Teacher at Federal University of Acre - UFAC, Cartography Laboratory, BR 364, km 4, Distrito Industrial, 69920-900, Rio Branco, AC, Brazil. ropereas@ gmail.com
\end{abstract}

Artigo recebido em 20/11/2018 e aceito em 11/02/2019

\section{A B S T R A C T}

The objective of this study was to investigate the hypothesis of stationary behavior in the streamflow regime of the upper Juruá river. For this purpose, annual maximum daily flow data recorded at stations located in Cruzeiro do Sul and Marechal Thaumaturgo, AC, Brazil, were analyzed using Mann-Kendall, Pettitt, and Spearman's Rho tests. The results show sufficient evidence to conclude that in Cruzeiro do Sul flow rates have an ascending temporal behavior, while in Marechal Thaumaturgo it is descending. However, this tendency is not significant $(\mathrm{p}<0.05)$, allowing to conclude in favor of the hypothesis of stationarity in the streamflow series of the referred basin. Thus, one of the physical implications associated to the results obtained may be the conclusion that the streamflow regime in the Upper Juruá basin has not changed significantly over time.

Key words: stationarity, annual maximum daily flow, Upper Juruá basin.

\section{R E S U M O}

O presente estudo tem o objetivo de investigar a hipótese de comportamento estacionário no regime de vazões do alto rio Juruá. Para tal, foram utilizadas as séries temporais de vazões diárias máximas anuais, gravados nas estações localizadas em Cruzeiro do Sul e Marechal Thaumaturgo, as quais foram analisadas por meio do teste de Mann-Kendall, de Pettitt e do Spearman Rho teste. Os resultados demonstram evidências suficientes para concluir que, em Cruzeiro do Sul, as vazões apresentam comportamento temporal ascendente, enquanto em Marechal Thaumaturgo descendente. Entretanto, tal inclinação não é significativa $(p<0,05)$, permitindo concluir em favor da hipótese de estacionariedade nas séries de vazões da referida bacia hidrográfica. Assim, uma das implicações físicas associadas aos resultados obtidos pode ser a conclusão de que o regime de vazões na bacia do Alto Juruá não sofreu alterações significativas ao longo do tempo.

Palavras-chave: estacionariedade, vazões máximas, Bacia do Alto Juruá.

\section{Introduction}

The need (or interest) to understand the components and the dynamics of hydrological processes and the use of hydrological resources dates back to the formation of the first civilizations, due to the fact that water is a fundamental element for diverse human activities. Scientific and technological advances have allowed the development of important tools for the management of available water resources. Such techniques allow and stimulate the study of hydrological alterations in hydrographic basins, especially in streamflows, and impact on resultant 
water availability for the most diverse uses, such as public supply, irrigation, power generation, etc. (Vilanova, 2014; Moreira et al., 2016a).

In the last decades, potential changes in climate patterns both on regional and global scales have become a relevant topic in academic and scientific circles. That concern is justified by the possible implications of such changes and especially by their influence on hydrological phenomena, since it is known that hydrological variables depend on the climate and its temporal and spatial changes (Penereiro and Orlando, 2013; Coopersmith et al., 2014).

The discussion about potential climate changes has motivated research on the various components of the hydrological cycle, especially those that allow the identification of possible trends or other non-stationarity factors in the records of hydrological variables along the time scale (Ávila et al., 2014; Uliana et al., 2015). According to Joseph et al. 2013, the verification of possible nonstationarities in hydrological series is important for the management and handling of hydrographic basins and their available resources. In addition to that, Uliana et al. 2015, emphasize that trend investigation is an important tool for many applications of hydrology, allowing to examine the temporal behavior of hydrological variables. Additionally, Penereiro and Orlando 2013, maintain that this type of investigation helps in the search for a regular occurrence of hydrological phenomena and supports the possibility of predictions that may assist in water resources use planning.

It is important to note that non-stationarity in a hydrological time series is a systematic and continuous change in any parameter of a given sample, excluding periodic or quasiperiodic changes from this definition. Non-stationarity types include trends, jumps or cycles over time (Naghettini and Pinto, 2007; Silva and Souza, 2013). There are many widely used tests for investigating non-stationarity in series of hydrological variables, including non-parametric tests. Among the latter, the most important ones are statistical tools specifically designed for this purpose, such as the Mann-Kendall test, the Spearman test and the Pettitt test (Back, 2001; Shadmani et al., 2012).

Thus, the present study intends to investigate the hypothesis of stationary behavior in the hydrological daily streamflow series of the hydrographic basin of the Upper Juruá river. For that, the author analyzed sample records from two fluviometric stations present in the region using non-parametric tests.

\section{Materials and methods}

\section{Study Area}

The study area comprises the sub-basin of the Upper Juruá River, located in a wide area of the Acre State in the Juruá Valley region, characterized by the predominance of large rivers and vast extensions of native forest (Acre, 2012).

Following the Köppen climate classification system, the predominant climate in the study region can be described as tropical rainforest (Af), wet and hot, with an average annual temperature around $24.5^{\circ} \mathrm{C}\left(76^{\circ} \mathrm{F}\right)$. The climate pattern is characterized by a dry period (May to September) and a notably rainy season (October to April), with average annual precipitations of approximately 2,000 mm (Delgado and Souza, 2014; Moreira et al., 2016a).

Regarding streamflows, the region is similar in character to the whole state of Acre, with a period of low flow rates and another with the highest recorded annual flows, coinciding respectively with the aforementioned dry and rainy periods. The dry, low-flow period is popularly known as the "Amazonian summer," while the rainy season with higher flows in the watercourses is known as the "Amazonian winter." In the heavy rainfall period, it is common for rivers to overflow their banks in their main channels, consequently invading their flood plains (Macêdo et al., 2013; Moreira and Naghettini, 2016).

\section{Hydrological Series}

This study was based on data recorded on two fluviometric stations located on the Juruá River: 12370000 and 12500000, in the municipalities of Marechal Thaumaturgo ( $8^{\circ} 56^{\prime} \mathrm{S}$; $\left.72^{\circ} 47^{\prime} \mathrm{W}\right)$ and Cruzeiro do $\mathrm{Sul}\left(7^{\circ} 38^{\prime} \mathrm{S}, 72^{\circ} 39^{\prime} \mathrm{W}\right)$, respectively (both in WGS84 datum) (Figure 1). The operational responsibility for these stations belongs to the Brazilian National Water Agency (ANA). 


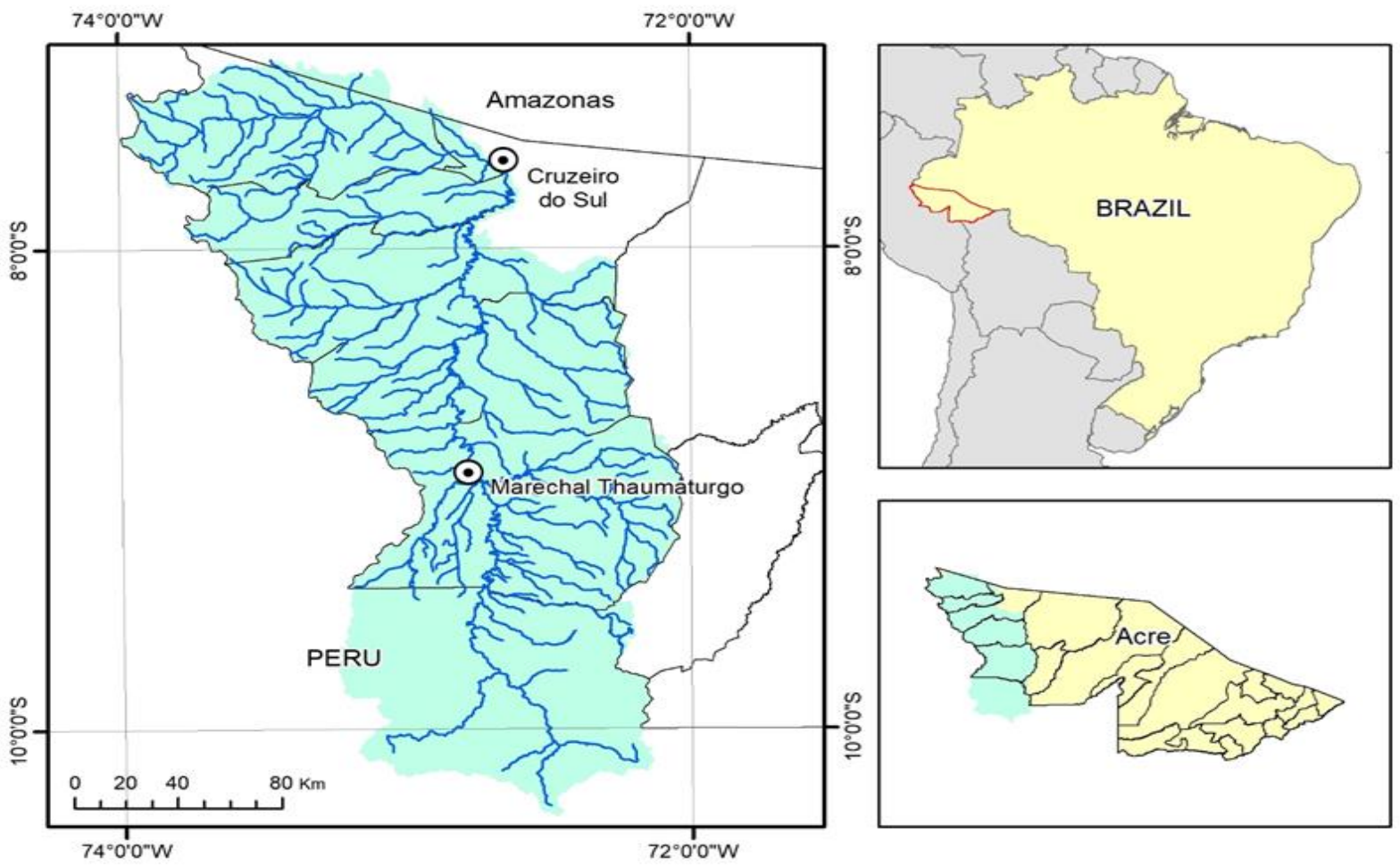

Figure 1: Location of the hydrographical basin of the upper Juruá river, State of Acre

The values used in this work are those referring to the annual and monthly daily maximum flows. The analysis considered data recorded from January 1982 to December 2011 in the Marechal Thaumaturgo station and data from January 1968 to December 2011 from the Cruzeiro do Sul station. Only the values already available in the ANA database, accessed through the HidroWeb platform, were considered.

It should be noted that in this region there are two other stations that were not included in the present study: one located in the Foz do Breu community (at the Brazil-Peru border) and another in the municipality of Porto Walter. Such exclusion is motivated by significant flaws in the data series of the Foz do Breu station, which could compromise the results of the analysis, while the second series covers a very short period and therefore could also influence the analytical decision about the presence or not of temporal trends.

\section{Statistical Tests}

\section{Mann-Kendall Test}

The Mann-Kendall test, also known as the MK test, is a non-parametric statistical test that is widely used to identify significant trends in longterm hydrometeorological series. Many authors report among their conclusions that the MK test has proven to be quite robust when analyzing nonstationarity and deviations from normality in a time series (Moreira et al., 2016a; Santos et al., 2016).

As described by Moreira et al. (2016a) and by Sanches et al. 2017, given a series (X1, X2,..., $\mathrm{Xn}$ ) from a sample of $\mathrm{n}$ independent, identically distributed random variables, the MK test is given by the following equation:

$$
S=\sum_{i=1}^{n-1} \sum_{j=i+1}^{n} \operatorname{sgn}\left(X_{j}-X_{i}\right)
$$

In which $X_{i}$ represents the values from the series (in this case, taken in annual time intervals); $i$ and $j$ are the time indices and $n$ is the number of elements in the series. The term $\operatorname{sgn}\left(X_{j}-X_{i}\right)$ is determined by the following equation:

$$
\operatorname{sgn}\left(X_{j}-X_{i}\right)=\left\{\begin{array}{c}
+1 i f\left(X_{j}-X_{i}\right)>0 \\
0 i f\left(X_{j}-X_{i}\right)=0 \\
-1 i f\left(X_{j}-X_{i}\right)<0
\end{array}\right.
$$

Mann 1945, and Kendall 1975, explained that the statistic $S$ follows approximately a normal distribution when $n \geq 8$. For data with no bound elements (equal values), the test statistic presents a mean $E(S)$ and variance $\operatorname{Var}(S)$ given respectively by:

$$
E(S)=0
$$




$$
\operatorname{Var}(S)=\left(\frac{1}{18}\right)[n(n-1)(2 n+5)]
$$

If there are bound points, variance is corrected by the following expression:

$$
\operatorname{Var}(S)=\left(\frac{1}{18}\right)\left[-\sum_{p=1}^{q} t_{p}\left(t_{p}-1\right)\left(2 t_{p}+5\right)\right]
$$

In which $t_{p}$ denotes the number of bound points from $p$ until $q$.

The significance of the MK test can be verified through a bilateral test, with the standardized statistic $Z_{M K}$ expressed as follows:

$$
Z_{M K}=\left\{\begin{array}{l}
\frac{S-1}{\sqrt{\operatorname{Var}(S)}} \text { if } S>0 \\
0 \text { if } S=0 \\
\frac{S+1}{\sqrt{\operatorname{Var}(S)}} \text { if } S<0
\end{array}\right.
$$

According to Moreira et al. (2016a), the null hypothesis $\left(H_{0}\right)$, for absence of trend in the series, is rejected if $\left|Z_{M K}\right|>Z_{\alpha / 2}$, in which $\alpha$ is the level of significance adopted and $Z_{\alpha / 2}$ is the value of the standard normal distribution with a probability of exceedance of $\alpha / 2$. The sign before $Z_{M K}$ indicates whether the trend is increasing $\left(Z_{M K}>0\right)$ or decreasing $\left(Z_{M K}<0\right)$. The level of significance most commonly used is $\alpha=0.05$. Having adopted it in the present study, $Z_{\alpha / 2}=$ 1.96. The p-value of the statistic $S$ for the sample data can be estimated by the cumulative probability for the normal distribution, considering that if $p \leq$ $\alpha$, the test presents evidence for the rejection of $H_{0}$, suggesting the presence of trends in the series.

\section{Pettitt's Test}

Pettitt's non-parametric test is used to verify the occurrence of an abrupt change, or change point, in a time series. This test uses a version of the Mann-Whitney test, which verifies if two samples $X_{1}, X_{2}, \ldots, X_{t}$ and $X_{t+1}, X_{t+2}, \ldots, X_{T}$ belong or not to the same population (Penereiro and Ferreira, 2011; Santos et al., 2016).

As described by Penereiro \& Ferreira 2011, and Penereiro et al. 2016, the Pettitt's test is based on the null hypothesis $\mathrm{H}_{0}$ : the hydrological series Xn shows no abrupt change, and its application is not conditioned by an a priori specification of the instant the change occurs (if it occurs). The statistic $U_{t, T}$ counts the number of times a member of the first sample is larger than a member of the second sample, as defined by the following equation:

$$
U_{t, T}=U_{t-1, T}+\sum_{j=1}^{T} \operatorname{sgn}\left(X_{i}-X_{j}\right), t=2, \ldots, T
$$

In which:

$$
\operatorname{sgn}(x)=\left\{\begin{array}{c}
1, \text { if } x>0 \\
0, \text { if } x=0 \\
-1, \text { if } x<0
\end{array}\right.
$$

With this, the statistic $U_{t, T}$ is calculated for values from $1 \leq t \leq T$ and the test statistic $\mathrm{K}(\mathrm{t})$ is the maximum absolute value of $U_{t, T}$, i.e.:

$$
K(t)=\underset{1 \leq t \leq T}{M a ́ x}\left|U_{t, T}\right|
$$

The statistic $K(t)$ locates the point where there was a sudden change in the mean of the analyzed time series (if there is any). Its significance can be verified using the following equation:

$$
p \cong 2 \exp \left(\frac{-6(K(t))^{2}}{T^{3}+T^{2}}\right)
$$

In which $\mathrm{p}$ is the level of significance and the null hypothesis $\left(\mathrm{H}_{0}\right)$ should be rejected if $p<\alpha$, being $\alpha$ the level of significance of the test, usually defined as $5 \%$, as in the present study. The abrupt change point is then the point in which the value of $\mathrm{t}$ occurs for the maximum value of $K(t)$ (Penereiro and Ferreira, 2011).

\section{Spearman's Rho Test}

Spearman's non-parametric test, the Spearman's Rho test or the SR test, aims to detect a possible temporal trend in a hydrological series by analyzing the correlation between the time index and the data from the series of observations (Naghettini and Pinto, 2007; Shadmani et al., 2012; Santos et al., 2016).

The Spearman test is based on the correlation coefficient between a classification order $m_{t}$, a sequence $X_{t}$, and time indices $T_{t}(1,2, \ldots, N)$. As described by Naghettini and Pinto (2007) and Shadmani et al. (2012), the SR test statistic is based on the coefficient determined from the following equation:

$$
r_{s}=1-\frac{6 \sum_{t=1}^{N}\left(m_{t}-T_{t}\right)}{N^{3}-N}
$$

Considering a hypothesis based on the absence of correlation between $m_{t}$ and $X_{t}$, it is 
demonstrated that, for $N>10$, the distribution of $r_{s}$ can be approximated by a normal distribution whose mean is null and whose variance is given by the following equation:

$$
\operatorname{Var}\left[r_{s}\right]=\frac{1}{N-1}
$$

Thus, with the null hypothesis $\mathrm{H}_{0}$ : "the sample has no temporal trend", the Spearman's Rho test statistic is formulated from the value obtained in Equation 13, which follows a standard normal distribution.

$$
T=\frac{r_{s}}{\sqrt{\operatorname{Var}\left[r_{s}\right]}}
$$

As this is a two-sided test, the most logical decision in this case is to reject the null hypothesis
$\left(\mathrm{H}_{0}\right)$ if $|T|>Z_{1-\alpha / 2}$, in which $\alpha$ is the level of significance adopted and $Z$ is the value of the standard normal distribution.

\section{Results and discussion}

First, it was verified that the historical mean of the annual maximum daily flows registered in Cruzeiro do Sul (12500000) in the studied period was of $3,243.9 \mathrm{~m}^{3} / \mathrm{s}$. The maximum value recorded in the period in said station was $4,430.4 \mathrm{~m}^{3} / \mathrm{s}$ in 1995 , while the minimum value was 2,059.4 $\mathrm{m}^{3} / \mathrm{s}$, recorded $(13)^{2006}$. At the Marechal Thaumaturgo station (12370000), the historical mean was of $2,319.9 \mathrm{~m}^{3} / \mathrm{s}$, with a maximum value of $2,796.7 \mathrm{~m}^{3} / \mathrm{s}$ recorded in 1986 and a minimum of $1,603.8 \mathrm{~m}^{3} / \mathrm{s}$, in 2005 (Figure 2).
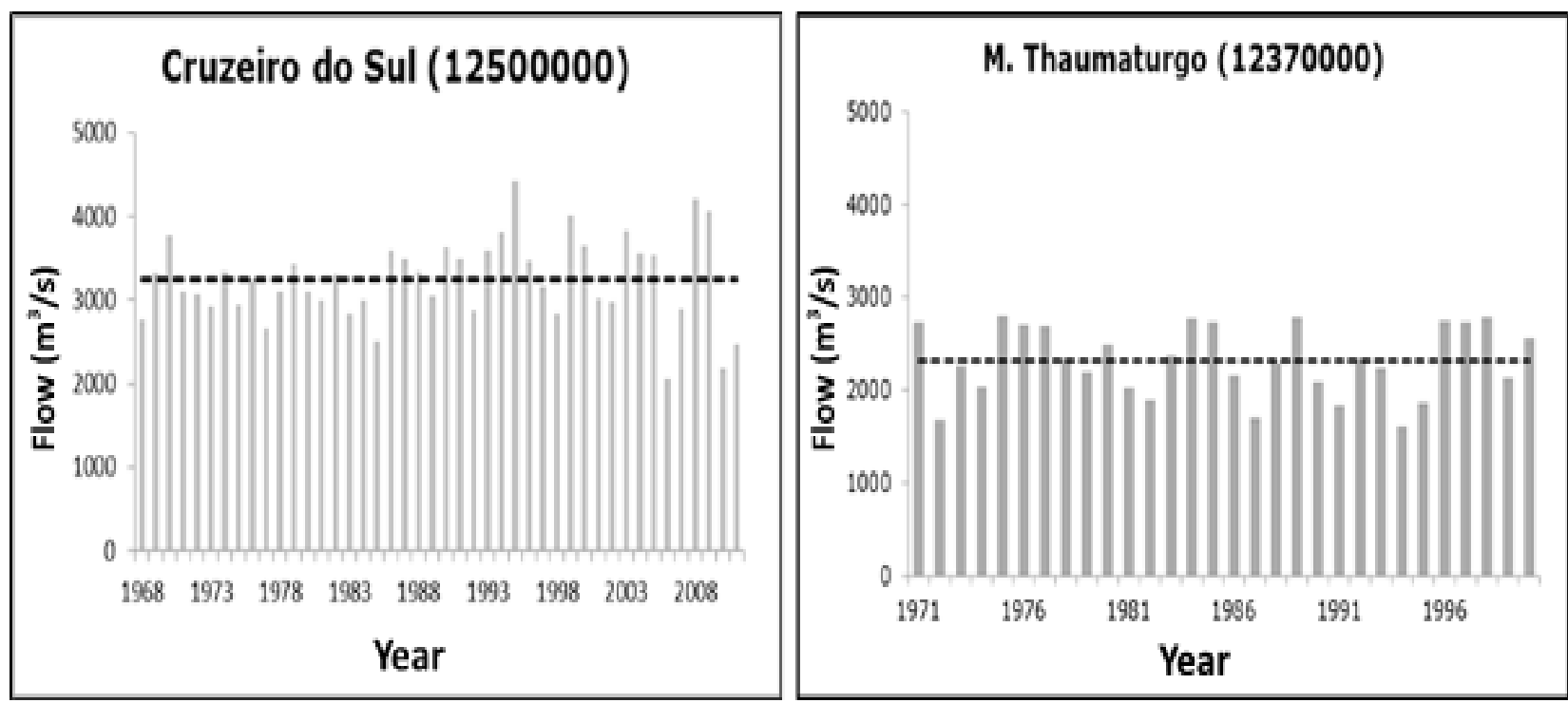

Figure 2: Annual maximum daily flow of the Upper Juruá hydrographic basin, Acre, Brazil. The horizontal reference line represents the historical mean calculated for the studied period.

These streamflow values are characteristic to Amazonian rivers, which tend to present high flow values and a large variation between the maximum and minimum values recorded, as reported by Moreira and Naghettini 2016, for these authors, the hydrological conditions of the region can be influenced by anthropic activities as well as by fluctuations in its climate patterns.
For the temporal record, it was verified that the values of the annual maximum daily flows recorded in Cruzeiro do Sul present an ascending behavior during the studied period. Figure 3 shows the graph that confirms this statement. The dotted line in said figure represents the linear trend of the values of the historical series studied. 

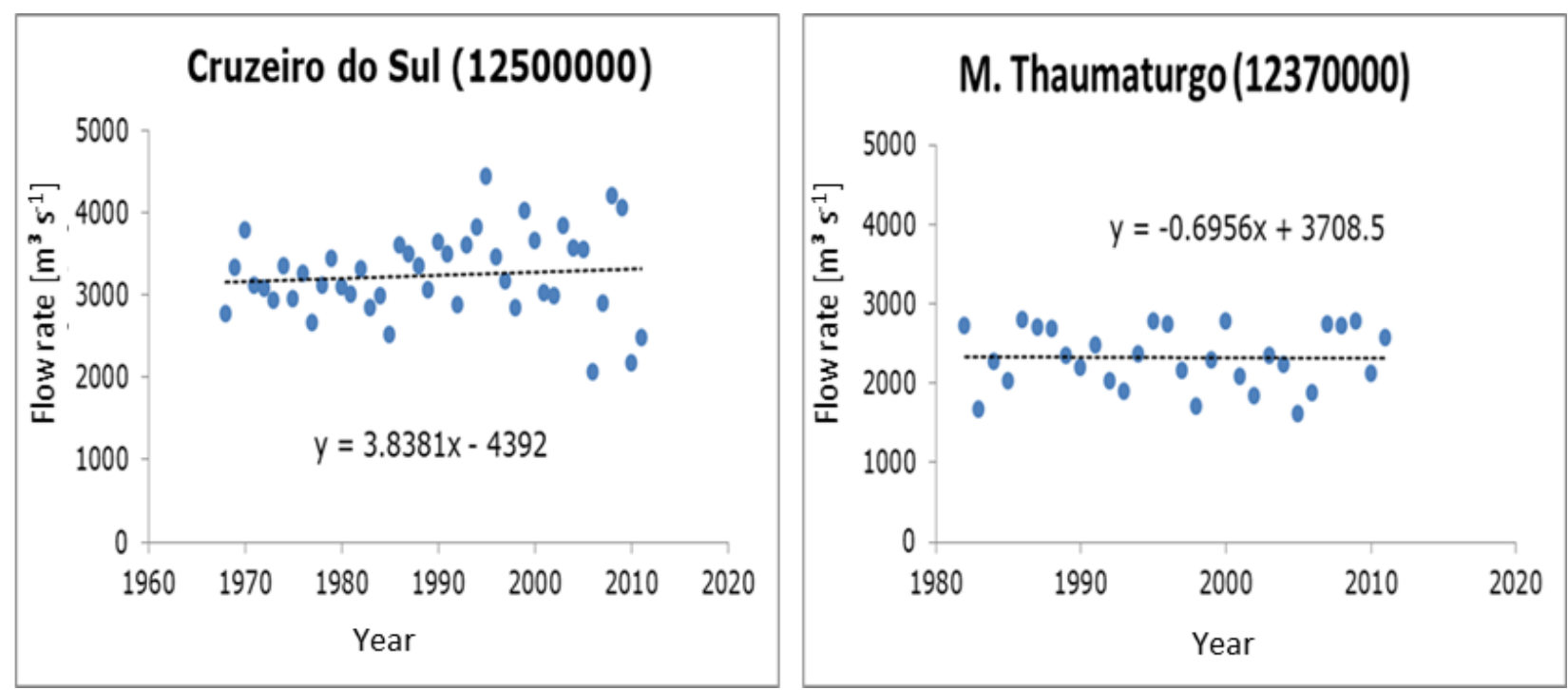

Figure 3: Temporal behavior of the annual maximum daily flow values recorded in the Cruzeiro do Sul and Marechal Thaumaturgo gauging stations, both located in the hydrographic basin of the Upper Juruá river,

Acre, Brazil.

In this sense, many studies report among their results a similar conclusion for streamflow and other hydrological variables (e. g. Shi et al., 2018; Gao et al., 2018; Kahya and Kalayaci, 2004). Among those, it is worth mentioning the work by Santos et al. 2016, who have detected an ascending behavior in the annual maximum daily flows recorded in the Pardo river, in the states of São Paulo and Minas Gerais, and the results obtained by Moreira et al. (2016a), who have found a similar behavior in the rainfall regime in Cruzeiro do Sul.

On its turn, data from the Marechal Thaumaturgo station describe a descending behavior in the records of annual maximum daily flows over time (Figure 3). In this sense, Marengo and Alves 2005, report a negative trend in the flow series from the Paraíba do Sul river, a trend which is significant for some gauging stations. The authors report that river flows are important indicators of climate variability and consider that increasing or decreasing trends in hydrological series can be explained by human influences.

Despite the ascending trend in the daily maximum flow records in Cruzeiro do Sul and descending trend for the values recorded in Marechal Thaumaturgo over time, the evidence obtained from the Mann-Kendall, Pettitt's and Spearman Rho tests converge by pointing to the non-acceptance of the hypothesis of a significant trend for the two studied series ( $\mathrm{p}<0.05)$. In all three tests, the p-value was greater than the level of significance previously defined $(\alpha=0,05)$.

Therefore, it is concluded that these series can be characterized as stationary.

Table 1 shows the results from each test.

Table 1: Summary of the results of trend, jump and stationarity tests in the series of annual maximum daily flows recorded in the hydrographic basin of the Upper Juruá river.

\begin{tabular}{c|c|c|c|c|c}
\hline \multicolumn{2}{c|}{ Cruzeiro do Sul (12500000) } & \multicolumn{3}{c}{ Marechal Thaumaturgo (12370000) } \\
\hline Test & Test Statistics & p-value & Test & $\begin{array}{c}\text { Test } \\
\text { Statistics }\end{array}$ & p-value \\
\hline $\begin{array}{c}\text { Mann- } \\
\text { Kendall }\end{array}$ & $\mathrm{Z}_{\mathrm{MK}}=1.052$ & $0.293^{\mathrm{NS}}$ & $\begin{array}{c}\text { Mann- } \\
\text { Kendall }\end{array}$ & $\begin{array}{c}\mathrm{Z}_{\mathrm{MK}}=- \\
0.1784\end{array}$ & $0.858^{\mathrm{NS}}$ \\
\hline Pettitt & $\mathrm{U}=175$ & $0.243^{\mathrm{NS}}$ & Pettitt & $\mathrm{U}=61$ & $0.898^{\mathrm{NS}}$ \\
\hline $\begin{array}{c}\text { Spearman's } \\
\text { Rho }\end{array}$ & $\mathrm{T}=0.926$ & $0.259^{\mathrm{NS}}$ & $\begin{array}{c}\text { Spearman's } \\
\text { Rho }\end{array}$ & $\mathrm{T}=0.035$ & $0.398^{\mathrm{NS}}$ \\
\hline
\end{tabular}

NS = not significant at the level of significance $\alpha=0,05$. 
The Mann-Kendall and Spearman's Rho tests showed a non-significant trend in the two series analyzed. In this sense, Alves et al. 2013, analyzed trends and patterns of variation in streamflow records made available by the Brazilian National Electric System Operator (ONS) and concluded that there are increasing trends in flow series in the South, Southeast and Central-West regions of Brazil, as well as decreasing trends in North and Northeast regions. According to the authors, such variations may cause impacts on the Brazilian hydroelectric capacity in the long term.

In a study on maximum rainfall recorded in Cruzeiro do Sul, Acre, Moreira et al. (2016a) report a non-significant ascending trend. studying climatological trends in Urussanga, Santa Catarina, Brazil, Denski and Back 2015, have found a significant ascending trend for the average annual temperature series, and not significant trends for series of other climate variables such as maximum and minimum temperature, relative humidity and wind speeds.

Still regarding temporal trends of series of climate-related variables, Shadmani et al. 2012, studied trends in Reference Evapotranspiration series in arid regions of Iran and identified both increasing and decreasing trends. The authors have emphasized the need for more studies on the behavior of variables that impact on the climate, such as flows, especially in the current context of possible changes in climate patterns.

There were no abrupt changes in the series of annual maximum daily flows in the the hydrographic basin of the Upper Juruá, and the analytical decision in favor of their absence was safeguarded by the results obtained using the Pettitt's test. The conclusions after studying the Upper Juruá basin are different from those obtained in an analysis of flow records from the Pardo River in the research conducted by Chierice Júnior and Landim 2014, who have verified a change in the flow regime recorded at the Fazenda Bela Vista station, near the outlet of the Rio Pardo basin. Uliana et al. 2015, found a significant trend as well as change points in rainfall and flow series in the city of Alegre-ES.

According to Santos et al. 2013, when there is a significant trend in the flow regime, that is, when there is stationarity in the series analyzed, diverse factors contribute to this characteristic. The authors warn that most flow records are affected by human activity that impacts on the climate factors operating in the river basin. In a recent study,
Uliana et al. 2015, subscribe to the same position and specifically warn that changes in land use and land occupation have direct effects on water infiltration capacity of the soil, consequently causing changes in the surface runoff regime. In turn, according to Moreira et al. (2016b) and Gao et al. 2018, many factors are reported among the possible causes of trends or non-stationarity in series of hydrological observations, including alterations attributed to anthropic actions as well as the effects of changes produced by the climate's natural variability. For the authors, the joint or isolated action of these elements may interfere, indeed, with the temporal regime of several climate variables, including flows. It may even increase the risk of occurrence of extreme events.

\section{Conclusions}

The present work aimed to put into question the analysis of stationarity in series of hydroclimatic observations. For the studied context, the Mann-Kendall, Spearman's Rho, and Pettitt's tests were used to analyze the series of annual maximum daily flows observed in the Upper Juruá hydrographic basin, considering the records from the gauging stations located in Cruzeiro do Sul and Marechal Thaumaturgo.

From a preliminary analysis, it was verified that the flow series recorded in Cruzeiro do Sul presents an ascending trend over time, while the series from Marechal Thaumaturgo shows a descending trend. Notwithstanding, the results of the tests were sufficient to conclude for not rejecting the hypothesis that the series analyzed are stationary.

Thus, one of the physical implications associated to the results obtained from the present study (series of stationary flows) may be the conclusion that the flow regime in the Upper Juruá basin have not changed significantly over time, in accordance with the conclusions reported in previous studies and highlighted in this work.

Despite the uncertainties associated with the climate processes that impact flow regimes, the results obtained in the present study are relevant and timely, and will serve as decision-support elements in the management of water resources. In addition, they can serve as a basis for other studies that corroborate with the conclusion here presented or even make evident additional elements on the dynamics of the fluviometric regime of the region. 


\section{Acknowledgments}

The authors thank CNPq, CAPES and UFAC for their support for this work.

\section{References}

Acre (State). 2012. Governo do Estado do Acre. Plano Estadual de Recursos Hídricos, SEMA, Rio Branco AC, 243p. Avail able from: < http://www.agencia.ac.gov.br/wpcontent/uploads/2017/03/PLERH interativo fi nal1.pdf > Accessed 18/07/2018.

Alves, B. C. C.; Souza Filho, F. A.; Silveira, C. S. 2013. Análise de tendências e padrões de variação das séries históricas de vazões do Operador Nacional do Sistema (NOS). Revista Brasileira de Recursos Hídricos, 18 ,194. Available from: <http://132.248.9.34/hevila/ RBRHRevistabrasileiraderecursoshidricos/201 3/vol18/no4/2.pdf > Accessed 18/07/2018.

Ávila, L. F.; Mello, C. R.; Yanagi, S. N. M.; Neto, O. B. S. 2014. Tendências de temperaturas mínimas e máximas do ar no Estado de Minas Gerais. Pesquisa agropecuária brasileira, v.49(4), 247-256. DOI: https://doi.org/10.1590/S0100204X2014000400002.

Back, A. J. 2001. Aplicação de análise estatística para identificação de tendências climáticas. Pesquisa Agropecuária Brasileira, 36 ,717-726. DOI: $\quad$ http://dx.doi.org/10.1590/S0100204X2001000500001.

Chierice Júnior, N.; Landim, P. M. B. 2014. Análise de chuva e vazão na bacia hidrográfica do Rio Pardo. Geociências, 33 , 244-260. Available from: <http://ppegeo.igc.usp.br/inde x.php/GEOSP/article/view/7344 > Accessed 18/07/2018.

Coopersmith, E. J.; Minsker, B. S.; Sivaplan, M. 2014. Patterns of regional hydroclimatic shifts: An Analysis of changing hydrologic regimes. Water Resources Research, 50, 1960-1983. DOI: https://doi.org/10.1002/2012WR013320.

Delgado, R. C.; Souza, L. P. 2014. Tendência da precipitação e seu aproveitamento para fins não potáveis na Amazônia Ocidental, Acre. Nativa, 2, 108-113. DOI: https://doi.org/10.14583/23187670.v02n04a04.

Denski, A. P. N.; Back, A. J. 2015. Tendência climatológica nos elementos meteorológicos e na evapotranspiração de referência de Urussanga-SC. Revista Brasileira de Climatologia, 17, 259-271. DOI: http://dx.doi.org/10.5380/abclima.v17i0.38400.

Gao, L.; Huang, J.; Chen, X.; Chen, Y.; LIU, M. 2018. Contributions of natural climate changs and human activities to the trend of extreme precipitation. Atmospheric Research, 205, 6069.

DOI: https://doi.org/10.1016/j.atmosres.2018.02.006.

Joseph, J. F.; Falcon, H. E.; Sharif, H. O. 2013. Hydrologic trends and correlations in South Texas River Basins: 1950-2009. Journal of Hydrologic Engineering, 18, 1653-1662. DOI: http://dx.doi.org/10.1061/(ASCE)HE.19435584.0000709.

Kahya, E.; Kalayci, S. 2004. Trend analysis of streamflow in Turkey. Journal of Hydrology. 289, 128-144. DOI: https://doi.org/10.1016/j.jhydrol.2003.11.006.

Kendall, M. G. 1975. Rank correlation Methods, Charles Griffin, London.

Macêdo, M. N. C.; Dias, H. C. T.; Coelho, F. M. G.; Araújo, E. A. Souza, M. L. H.; Silva, E. 2013. Precipitação pluviométrica e vazão da bacia hidrográfica do Riozinho do Rôla, Amazônia Ocidental. AmbiÁgua, 8, 206-221. DOI: http://dx.doi.org/10.4136/ambi-agua.809.

Mann, H. B. 1945. Non-parametric tests against trend. Econometria. 13, 245-259. DOI: https://doi.org/10.2307/1907187.

Marengo, J. A.; Alves, L. M. 2005. Tendências hidrológicas da bacia do rio Paraíba do Sul. Revista Brasileira de Meteorologia, 20 , 215$226 . \quad$ http://dx.doi.org/10.18406/2316$1817 \mathrm{v} 6 \mathrm{n} 32014601$.

Moreira, J. G. V.; Craveiro, R. L.; Serrano, R. O. P.; Formolo, A. K. 2016a. Temporal trend and frequency of maximum precipitations in Cruzeiro do Sul, Acre, Brasil. Nativa, 4, 97-102. http://dx.doi.org/10.14583/23187670.v04n02a08.

Moreira, J. G. V.; Naghettini, M. 2016. Detecção de tendências monotônicas temporais e relação com os erros dos tipo I e II: Estudo de caso em séries de precipitações diárias máximas anuais do estado do Acre. Revista Brasileira de Meteorolorgia, 31, 394-402. DOI: http://dx.doi.org/10.1590/0102778631231420140155.

Moreira, J. G. V.; Naghettini, M.; Eleutério, J. C. 2016b. Frequência e risco sob não- 
estacionariedade em registros pluviométricos na bacia do alto rio Tarauacá, Acre. Revista Brasileira de Recursos Hídricos, 21, 232-241. DOI:

http://dx.doi.org/10.21168/rbrh.v21n1.p232241.

Naghettini, M. C.; Pinto, E. J. 2007. Hidrologia Estatística, CPRM, Belo

Horizonte. 552p. Available from: < http://www .cprm.gov.br/publique/Hidrologia/Mapas-e-

Publicacoes/Livro-\%22Hidrologia-

Estatistica\%22-981.html> Accessed 18/07/2018.

Penereiro, J. C.; Ferreira, D. H. L. 2011. Estatística apoiada pela tecnologia: uma proposta para identificar tendências climáticas. Acta Scientiae, $\quad 13(1), \quad 87-$ 105. Available from: <http://www.periodicos.u lbra.br/index.php/acta/article/viewFile/25/22> Accessed 18/07/2018.

Penereiro, J. C.; Orlando, D. V. 2013. Análise de tendências em séries temporais anuais de dados climáticos e hidrológicos na bacia do rio Parnaíba entre os estados do Maranhão e Piauí/Brasil. Revista Geográfica Acadêmica, 7, 5-21. DOI: http://dx.doi.org/10.18227/16787226rga.v7i2.2988.

Penereiro, J. C.; Martins, L. S.; Beretta, V. Z. 2016. Identificação de variabilidades e tendências interanuais em medidas hidro-climáticas na região hidrográfica do Tocantins-Araguaia, Brasil. Revista Brasileira de Climatologia, 18, 219-241. DOI:

DOI: http://dx.doi.org/10.5380/abclima.v18i0.38840.

Sanches, F. O.; Silva, R. V.; Ferreira, R. V.; Campos, C. A. A. 2017. Climate change in the Triângulo Mineiro Region - Brazil. Revista Brasileira de Climatologia, 21, 570-587. DOI: http://dx.doi.org/10.5380/abclima.v21i0.51867.
Santos, C. A.; Lima, A. M. M.; Farias, M. H. C. S.; Aires, U. R. V.; Serrão, E. A. O. 2016. Análise estatística da não estacionariedade de séries temporais de vazão máxima anual diária na bacia hidrográfica do rio pardo. Holos, 7, 179193.

DOI: http://dx.doi.org/10.15628/holos.2016.4892.

Shadmani, M.; Marofi, S.; Roknian, M. 2012. Trend Analysis in Reference Evapotranspitation Using Mann-Kendall and Spearman's Rho Tests in Arid Regions of Iran. Water Resources Management, 26, 211-224. DOI: http://dx.doi.org/10.1007/s11269-011-9913-z.

Shi, J.; CUI, L.; MA, Y.; DU, H.; Wen, K. 2018. Trends in temperature extremes and their association with circulation patterns in China during 1961-2015. Atmospheric Research, 212, 259-272.

DOI: https://doi.org/10.1016/j.atmosres.2018.05.024.

Silva, D. F.; Souza, A. B. 2013. Detecção de tendências climáticas no estado de Alagoas. Revista Brasileira de Geografia Física. 6, 442455. Available from: < https://periodicos.ufpe.br/revistas/rbgfe/article/ view/232978> Accessed 18/07/2018.

Uliana, E. M.; Silva, D. D.; Morgan Uliana, Estevão; Rodrigues, B. S.; Corrêdo, L. P. 2015. Análise de tendência em séries históricas de vazão e precipitação: uso de teste estatístico não paramétrico. Revista Ambiente \& Água, 10, 8288. DOI: http://dx.doi.org/10.4136/ambiagua. 1427.

Vilanova, M. R. N. 2014. Tendências hidrológicas na região do alto rio Mogi-Guaçu, Sul de Minas Gerais. Revista Agrogeoambiental, 6, 63-70. DOI: $\quad$ http://dx.doi.org/10.18406/23161817v6n32014601. 